\title{
On the Effect of Inferiority on Love in Of Human Bondage Based on Inferiority Compensation Theory
}

\author{
Xiu Zeng ${ }^{1}$ \\ ${ }^{1}$ Foreign Language School, Nanchang Normal University, Nanchang, Jiangxi, China \\ Correspondence: Xiu Zeng, Foreign Language School, Nanchang Normal University, No. 889 Ruixiang Road, \\ Economic Development Zone, Nanchang City, Jiangxi, China. E-mail: 2267395464@qq.com
}

Received: July 8, 2020 Accepted: August 7, 2020 Online Published: August 18, 2020

doi:10.5539/ells.v10n3p100 URL: https://doi.org/10.5539/ells.v10n3p100

\begin{abstract}
Of Human Bondage, one of W. S. Maugham's great works, is supposed to be created on the basis of the real life of the author. It centers on the psychological growth of the hero, Philip, from a crippled boy to a mentally matured man. Following Alfred Adler's theory of inferiority compensation, through a close look into Philip's experiences with different women in his life, this paper tries to probe into the effect that the initial inferiority in Philip could produce on his view of love and also on his mentality and aims to explore the compensation Philip seeks to get for what he is deprived of in his early age.
\end{abstract}

Keywords: inferiority, compensation, love, Bondage

\section{Introduction}

Of Human Bondage, the longest novel and a masterpiece written by William Somerset Maugham, a celebrated English novelist, brings great fame and literary recognition to the author. It is generally agreed by many critics that this novel is of great literary value and it is popular with many readers all over the world. It mainly tells the personal growth of the hero-Philip, who is crippled in childhood, loses his parents at young age, and then lives with his uncle who is hypocritical and seems to show apathy to suffering and misery of people. Sent to a boarding school where he has difficulty fitting in, he grows up with an intense longing for love and company. Insufficient care and affection from parents then result in a birth of an initial inferiority in Philip. Because of inborn cripple, he often suffers mockery and isolation from his classmates after he enters school. Since then he has had all his hope and desire for love cherished in his heart. Later on, in his adulthood, he meets different women and his relationship with them is the major part of the novel. Whether these women love him or not, they all help Philip to grow and understand the nature of love between men and women. Philip's relationship with Mildred, a snobbish and vulgar waitress, is the focus of the whole novel, because she wakes up Philip's longing for love and care. In the end, through his struggles, he gets rid of the chain of inferiority in him and finds the true nature of love. At the end of the story, he chooses to marry Sally, an ordinary girl showing motherly love towards him, and begins to live a cozy life in a small fishing village for the rest of his life.

Of Human Bondage has attracted interest and attention from lots of critics since its publication. In the West, Michelle (2007) once said that "Maugham's novel provides us with a new opportunity to elucidate schema-focused therapy through the process of identifying Philip's temperament, his early maladaptive schemas, his long-term maladaptive coping styles, and his schema modes" in "A schema-focused analysis of Philip Carey in W. Somerset Maugham's "Of Human Bondage" ".

In China, Wang (2018) has studied the female tragedy caused by personal experiences and social prejudice. She analyzed the miserable life experiences of the five characters in the novel, each of whom has some common problems. And at the end of the article, she has found some ways for the women to fight against the stern bondage of social discrimination in the view of female independence.

Ji (2015) wrote a dissertation called "On the Exchange of Affection in Maugham's Of Human Bondage" in which She explored the exchange of affection in Of Human Bondage in terms of cost and reward, pointed out that the improper cognition of love, the degradation in morality and other human weaknesses led to the failure in the exchange of affection.

Liu (2014) produced an article entitled "The Analysis of the Essence of the Life of Philip Carey in Of Human 
Bondage" to demonstrate the impetus for Philip to search for the essence of life and to elaborate the process to find out the essence of life.

The main point in my thesis is to understand the inferiority in Philip and study the influence of inferiority on him under the light of inferiority compensation theory by Alfred Adler. As we know, with progress of science and technology, people are more likely to enjoy career success than ever before and family life is more likely to be devoted to making money and keeping up with the Joneses that they will neglect personal emotion, thus problems will arise. This thesis tries to provide another way to rethink about personal emotion and exchange of love in a proper way. First, the paper offers a new way for people to understand Philip. Second, it helps people learn something about inferiority compensation theory, and they can work out their own ways and get courage to get rid of the bondage of inferiority in themselves. Third, it tells us to care more about children in school and in family, for childhood experiences have much impact on the later life.

\section{Background of the Creation}

William Somerset Maugham is known as an accomplished writer, dramatist and essayist in England in the Victorian time. He has made magnificent success in writing and left a great number of masterpieces, and he is regarded as the 'Maupassant of England'. Of Human Bondage is said to be a semi-autobiographical novel. William Somerset Maugham lost both his parents when he was very young, he was fostered by his uncle who was a selfish and austere vicar in England. Entering Canterbury school, he suffered ridicule and mockery from the seniors for his serious stammer and small size. The loneliness and misery in childhood cast a shadow on his heart, which causes him to be sensitive and keep himself isolated from group. Of Human Bondage is viewed as a semi-biography of the author himself because in this book he has pictured a character called Philip, who has the same life experiences as he did.

Of Human Bondage was composed during the First World War when many countries were plunged into a full-scale crisis. In the early decades of the 20th century the West was in a crisis of economy, politics and belief. The World War brought people to a new era where their traditional belief was challenged by new reality. Thus, humans began to seek ways to get away from the bondage of old belief. William Somerset Maugham witnessed all the social changes and he spent ten years devoting himself for the composition of the remarkable novel, $O f$ Human Bondage. In this book, he conveys his complex feelings, especially sympathy, to the sufferings of the people living at the bottom of social ladder, who are overwhelmed by the chaotic economy, turbulent politics.

\section{Inferiority Compensation}

Alfred Adler, an Austrian psychiatrist, the founder of individual psychology, the first one to coin the term "inferiority complex", puts forward that every child experiences the feelings of inferiority as a result of being faced by stronger and more powerful adults. Growing up, a child will often feel incapable of getting certain skills, knowledge etc. As the child grows into an adult, this sense of inferiority persists and shows itself in various ways, most typically in a frustrated desire for perfection and recognition. This sense of self-doubt and sometimes lack of self-esteem is termed "inferiority complex" by Alfred (1920).

"Everyone has a feeling of inferiority. But the feeling of inferiority is not a disease; it is rather a stimulant to a healthy, normally striving and improving life. It becomes a pathological condition only when the sense of inadequacy overwhelms the individual and, far from stimulating him to a useful activity, makes him depressed and incapable of development."

Adler did not think this pathological sense of inadequacy was universal. In contrast, he believed that those who are able to escape it would often strive to overcome the early, original inferiority by facing the world with a proper problem-solving attitude. The feelings of self-improvement would bring a certain relief from the feelings of inadequacy. In a sense, the inferiority becomes a motivation to drive individual forward. The inferiority stimulates people to overcome obstacles in their life, what they will do is to build a sense of superiority to make compensations for the inferiority in their mind.

Adler followed Sigmund Freud early. Around the 1910s, however, he got away from the Freudian school as he grew more convinced that individual outlook, and not necessarily sex and sex drive, influenced human behavior. Adler's theories on inferiority and compensation were two of the major elements that drove him from Freudian psychoanalysis. And he claimed that both exterior factors and interior psychology had the same impact on people, and that sexuality was not the explanation for all problems and sexuality was overrated by Freud (Rao, 2012, p. 19).

\section{The Compensation for Inferiority in Philip's Love and Marriage}

Everyone more or less suffers a sense of inferiority which originates from the frustration he has experienced in 
childhood. Never has Philip got much warmth and love at school or at home, the inferiority in him becomes intense and then engulfs his mind. He has a strong desire to cast off the mental shade of being powerless, lonely and inferior. Therefore, he goes out to seek and compensate for what he is deprived of in his early age.

\subsection{In Association with Wilkinson}

As Philip grows up into adulthood, it is possible that he would strongly desire for care and love. He is looking forward to meet a girl with whom he may fall in love. When he first meets Wilkinson, an elaborately-dressed girl, he is shy and awkward. When he begins to have regular contact with Wilkinson, he knows little about how to get along with others, let alone with girls. On the one hand, he is still trapped in inferiority from boyhood. On the other hand, he is much striving for love in heart. Though he remains silent and uneasy in the communication with Miss Wilkinson, she apparently does not notice it and mind it. It is pleasant for her to have such an agreeable listener. It is the first time that Philip gets respect from others, especially from girls. Even though he does not have much affection and love for Wilkinson, he gets great delight and satisfaction in the communication. Conversation goes quite easily and enjoyably between them, it is Wilkinson who helps him build up confidence in the connecting with people. He is often excited with her conversation because of her humor and volubility.

The relationship with Wilkinson not only wakes up his awareness of love, but also frees Philip from the plight, caused by his physical defect and his early bitter experiences. Though he sometimes feels silly and is afraid of making a fool of himself in front of girls, he gradually gains confidence and recognition and makes a little compensation for his inferiority. Alder's theory tells us that a person would have an inner drive to make an improvement in the following love affairs despite of failure in the first one, and this is indeed true in the case of his relationship with Mildred.

\subsection{In Morbid Love with Mildred}

Maugham has contributed almost a half length of the novel to the depiction of the relationship between Philip and Mildred. Although the association with Wilkinson ends, Philip does not give up his desire to seek love for himself. When he comes across Mildred, a waitress working in a tea shop, he falls desperately in love with her though she has no love for him. Philip behaves awkward and is laughed at by the waitress and his pride is hurt. He is hurt again when Mildred gets married with another man and returns to seek his help in time of difficulty. The confidence he has built up in the relationship with Wilkinson is destroyed severely by Mildred. He could not bear being looked down upon by a vulgar, shallow and snobbish woman whom he tries to please. Finally, Philip helps her overcome trouble, only out of sympathy, and not out of love.

The affair with Mildred is totally different from his romantic illusion. Mildred is vulgar, thin, unhealthy and empty-minded, she is not as pure as Philip imagines. When Philip has a picture of her face in mind, he is seized by an uprush of emotion. He yearns for her and thinks of taking her in his arms, and kissing her. Philip's love for Mildred is out of reason, just to satisfy his lust and hope, to meet the hunger of soul or body. He can't help loving Mildred, because he believes that it is the only way that he can make up to get rid of the shade from his childhood. When Mildred is abandoned by her lover, she gets support from Philip who knows of her wretched experience. She accepts all that Philip does for her as if it were taken for granted in the world, and on the other hand he loves to spend money on her. He tries his best to offer Mildred some help, which is a great sense of satisfaction and pride for him. He does not care if she is heartless, stupid, vicious and vulgar, he simply loves her. It is not difficult to explain why Phillip is willing to suffer the anguish and bitterness brought about by Mildred, because he wants to find the value of himself in the world.

The morbid love drives him into a loss. It seems to him that he is carried away by every change of emotion, as though he were a leaf in the wind, and when passion seizes him he is powerless. Although he is often controlled by emotion, he never gives himself up for a better life. He tries his best to cast off the shadow and depression over him.

\subsection{In True Love with Norah}

When Mildred betrays him, Norah comes into his life and lights his hope for love again. Norah, an optimistic, humorous, voluble and considerate woman, is separated from her husband and earns her living and her child's living by writing novels. Norah's gentle care brings love and comfort to Philip's broken heart. Compared with Mildred, Norah is very perfect, with ready intelligence and amusing tone, they soon fall in love with each other. As for Philip, Norah gives him the comfort and maternal love that he lost as a child.

Philip tells Norah the whole story of his love, but what he gets from Norah is not a sarcastic and contemptuous response, but the deep sympathy and console which gives him self-esteem. Philip is much fond of her, glad to be with her, amused by and interested in her. She restores his belief in himself and puts healing ointments, as it 
were, on all the bruises of his soul. He admires her courage and is much delighted with her, with her vigor and with her optimism. Even for his deformity, Norah tries to relieve him from suffering in much tenderness. To his pleasant surprise, Norah has much admiration for him, he is pleased and satisfied on hearing this. In the following days, she acts like his mother, encouraging him, accompanying him, and bringing warmth to him.

Under her selfless care, love and affection, Philip gains personal confidence and enjoys his happiness in her company in the daily life. And because his desires for love and care are satisfied, he becomes more approachable and it is easier for people to get along with him. With her encouragement, he builds a connection with the world again, he passes the qualification examination designed for a doctor and lives a normal life as an ordinary man does. He makes great efforts to heal the bruise of soul. Though they break up at the end of the story, then the desire to win love encourages him to make continuous endeavors to get into the outer world and to fight against inferiority feelings.

\section{The Possible Causes for Inferiority in Philip in Childhood}

\subsection{Physical Deformation}

Individual psychology by Alder suggests that inadequacy in body will retard one's physical or mental progress, it is illustrated in the advance of human history. At the beginning of human civilization, usually the strongest and the most powerful man could be made the head of a tribe. In this way he could protect his tribe when they were endangered by any invaders and he could turn his tribe into a more powerful one. Possibly, man feels inferior or ashamed of himself or lives in constant fear when faced by more muscular or physically stronger men. The children with physical disability suffer the same when they are surrounded with strong classmates. Subsequently, the frustration the child experiences in his early life will take his confidence away and drive him away from crowd, making him lose connection with the world, being isolated and lonely.

To take a broad view, in the early 20th century, the world suffered the most severe economic, political and spiritual crisis. Living in such turmoil, Philip has to endure much more mental pressure. Before he enters school, he can avoid hurt and humiliation from others, but after he gets into the boarding school, he can not withdraw himself away from mockery and ridicule because of his club-foot. He has to stand alone beside the playground when the other kids run quickly and happily in front of him. One time, for example, the boys are playing the game "the Pig in the Middle" on the playground as usual, then one of them has an idea of imitating Philip's clumsiness in walking, the boys see it and begin to laugh "...limping grotesquely, screaming in their terrible voices with shrill laughter" (Maugham, 2013, p. 46). All of them enjoy the delight of this new amusement which brings more fun to them than the game itself. Poor, helpless Philip is totally scared of their laughing. He only knows that his heart beats so hard that he could hardly breathe, and he is more frightened than he has ever been in his life. This experience has cast a horrible shadow on his heart. For a long time, he is in agony, being painful and humiliated. He loses confidence in communication with other boys, trying to escape from the attention and then tease of people. As a matter of fact, he stays out of connection with his group, he learns to keep distance from his classmates in order to protect himself. Thus, he loses interest in the wonderful and changeable world. At the age when he should have been nurtured with love and friendship, he is overpowered by hostility and indifference from his classmates for his deformity, He loses faith in integrating himself into the world, instead, he struggles to find a way to escape.

\subsection{Unfamiliar Environment and Loneliness}

After the death of his parents, Philip is raised by his uncle Mr Carey, an apathetic and mean vicar. The days spent at his uncle's home are not as happy as they used to be in his own home. At the funeral for Philip's mother, Mr Carey cares more about the burden and troubles that he has to take to look after his nephew than Philip's sorrow in loss of his mother. Philip is not welcomed by his uncle, his request to take his nanny to live with him is rejected, for it will cost his uncle much more money to hire a nanny. "Philip, your father didn't leave much, and I don't know what's become of it. You must look at every penny you spend" (Maugham, 2013, p. 7). As for Mrs Carey, she is kind enough to try to help him get rid of the sorrow quickly, but she has never fostered a child and has no idea about how to get along well with Philip. Further, when Philip lives with them, his uncle makes rules for what he is expected to do or what he is not, he gets unaccustomed to it, and gradually gets as far away as possible from his uncle. There is no other children around for him to stay together with, his aunt attempts to take a good care of him, but she does it in an awkward way. For lack of mutual communication and trust between them, a gap in their relationship in the family follows.

\section{Reflection on the Power of Love}

After Philip has met with all the challenges in life through trial and error, he begins to understand what love is 
and what life is. He finds it very comfortable to be care-free and to have enough money to satisfy his needs. He is content with life, and he finally knows who would be a proper marriage partner for him, he chooses to live with Sally in a simple and happy way to the end of his life.

His inferiority complex has been compensated gradually, and he has gained the ability to love and live a normal life. When he knows that Sally has been in love with him for a long time, his inferiority is cured. It is the first time that he is much admired by a girl wholeheartedly. Before he falls in love with Sally, he does not know how to take care of his emotion, he tends to mix passion with cries, tear with vehemence. With Sally becoming his wife, Philip is sure that she will be there, glad to be with him, shouldering responsibility and going through hardship in life with him. It is the magic power of love that brings warmth and security to Philip and cures him.

Struggling with hardships in life, he gains rebirth and casts off all bondage that has been pressing him in one way or another. He decides to spend his life with Sally at a small village. He pictures to himself the long evenings he will spend with Sally in a sitting-room, living a happy and carefree life. All the past days are of little importance, compared with his growth from a weak-minded boy to a strong and powerful man. And he finally understands the nature and power of love.

\section{Conclusion}

Of Human Bondage is the story of a young man's struggle to find the nature of love and life in a cruel world. Being a laughing stock at school and in a group of adults, Philip suffers much in silence, enduring hard only to try to find someone to love him for the sake of love. It is the longing for happiness that makes this novel one that readers of all ages will identify with.

Everyone can learn a lot and understand life philosophy better on the basis of one's own life experiences. The women Philip meets in life contribute much to his gradual growth from a vulnerable boy to a strong man. Philip's emotional education is the work of several women, chief among them are Mildred and Sally, who in one way or another teach him and help him to get out of the shade of inferiority since childhood and build a will to make compensations for the inferiority in the mind.

\section{Acknowledgment}

This paper is funded by 11531 project of Nanchang Normal University.

\section{References}

Alfred, A. (1929). The Science of Living. London: LOWE AND BRYDONE PRINTERS.

Ji, C. Y. (2015). On the Exchange of Affection in Maugham's Of Human Bondage. Xiang Tan university.

Liu, L. L. (2014). The Analysis of the Essence of the Life of Philip Carey in Of Human Bondage. Collection of Short Stories.

Maugham, W. S. (2013). Of Human Bondage. China: Liaoning People's Publishing House.

Rao, Y. L. (2012). Overcoming Inferiority--the Interpretation of Philip's Growth in Of Human Bondage. Guang $\mathrm{Xi}$ university.

Skeen, M. (2007). A schema-focused analysis of Philip Carey in W. Somerset Maugham's "Of Human Bondage". The Wright Institute, ProQuest Dissertations Publishing.

Wang, J. (2018). Philip, The Trapped Swain in Of Human Bondage (p. 27). English on Campus.

\section{Copyrights}

Copyright for this article is retained by the author, with first publication rights granted to the journal.

This is an open-access article distributed under the terms and conditions of the Creative Commons Attribution license (http://creativecommons.org/licenses/by/4.0/). 